\title{
TMOD3 wt Allele
}

National Cancer Institute

\section{Source}

National Cancer Institute. TMOD3 wt Allele. NCI Thesaurus. Code C98056.

Human TMOD3 wild-type allele is located within 15q21.1-q21.2 and is approximately 83 $\mathrm{kb}$ in length. This allele, which encodes tropomodulin-3 protein, plays a role in microfilament stabilization. A chromosomal inversion that causes the promoter of the TMOD3 gene to fuse with the CYP19A1 gene may be associated with gynecomastia. 